\title{
Chuchotage - Intermediary Spaces in (Screen) Translation
}

\author{
Zsuzsanna AJTONY \\ Sapientia Hungarian University of Transylvania, Cluj-Napoca \\ Department of Human Sciences, Miercurea Ciuc \\ ajtonyzsuzsa@uni.sapientia.ro
}

\begin{abstract}
The present paper is devoted to the translation theoretical, linguistictextual comparison of the Hungarian film dialogues and their English subtitles of the short dramedy entitled Susotázs [Chuchotage, 2018] and directed by Barnabás Tóth, winner of several film festivals and shortlisted for Academy Awards in 2019. Subtitling is considered to be a form of rewriting, requiring text reduction through condensation, reformulation, and omission at word and/or sentence level (Díaz Cintas-Remael 2007). Following the theoretical considerations regarding the linguistic aspects of subtitling and its strategies, the paper discusses several aspects of rendering the Hungarian dialogue in the form of English subtitles, such as forms of address, informal expressions, and culture-specific elements. Finally, the analysis aims to highlight the possibilities of making Hungarian humour available in English.
\end{abstract}

Keywords: Hungarian film dialogue, English subtitles, interlingual transfer, humour, translation strategies

Motto:

Chuchotage ['usota:u]: The most difficult form of interpreting, where the interpreter does the simultaneous interpreting without the help of an interpreting system or equipment. Sitting next to the customer, the linguist whispers the interpretation of what is being said by the others but interprets the customer's words aloud. The form of interpreting can only be carried out with sufficient quality where only a very small number of people require interpreting.

(source: Society of Hungarian Translators and Interpreters)

\section{Introduction}

Translation is a special space in-between. It offers the target culture receiver a glimpse into another culture. Interlanguage subtitling as a form of audiovisual translation (AVT) has its pivotal role in allowing the audience of a film to have aural and visual access to the source culture. When a foreign language film is 
subtitled into English, one of its objectives is to make it accessible, i.e. to offer equivalent information to different audiences (Gambier 2018: 54). Subtitling a Hungarian audiovisual text into English intended for an international audience requires much attention from the translator in order to achieve the greatest impact possible. We believe that the quality of the translation directly influences the cultural impact of the source culture (SC) on the target culture (TC) (see Eco's cultural equivalence (2008) and House's functional equivalence $(1997,2015)$ ). Due to the strong position of the Anglo-American culture, as TC on the film market with respect to the Hungarian SC, today, when marketing and distribution are of major importance, a film targeted at international festivals and markets should heavily rely not only on its filmic/visual qualities but also on the English subtitles that the film is to be released with. When a relatively minor language and culture strives to achieve international attention, one major possibility to accomplish this is through quality translations from the minor language (in our case, Hungarian) into English, at the moment still the lingua franca of international culture. In this way, it might be possible to achieve that both the source and the target text will have the same status in their cultural systems (as argued in Bassnett 2007).

The present study aims to analyse the relationship between the Hungarian script and the English subtitles of the short Hungarian film Chuchotage (2018) directed by Barnabás Tóth in order to see whether the subtitling of the film contributes to its successful international reception.

So far, this only 16-minute-long film has won 20 awards, 22 nominations in 42 international film festivals ${ }^{1}$ and was shortlisted for Academy Awards (Oscar) nomination for the Best Live Action Short Film category in 2019.

\section{Theoretical considerations}

Translation, in general, requires flexibility and creativity from the translator, and this is even more valid in the case of subtitling due to its spatial and temporal constraints. In spite of the ubiquity of the image in our time, a good reception of a film can be achieved if its three main components - the spoken word, the image, and the subtitles - are in perfect symbiosis. In this respect, intersemiotic cohesion should be attained: the subtitles connect language directly to the soundtrack and to the images visible on the screen in order to achieve a coherent linguistic-visual whole (as argued in Díaz Cintas-Remael 2007: 171).

As opposed to dubbing, which sets only the target text available for the audience and leaves the source text covert, therefore being a more target-culturebound, i.e. domesticating strategy, subtitling is a more source-culture-bound, i.e. foreignizing strategy, which leaves both the source and the target text overt,

1 Source: Barnabás Tóth’s personal webpage: http://www.barnabastoth.com/. 
specifically audible and visible for the viewers (Szarkowska 2005, ShuttleworthCowie 1997: 45).

One of the earliest definitions of subtitling has been given by Gottlieb in 1992:

Benefiting from the support and counteracting the pressure from the array of formal and textual constraints, the subtitler transcodes the uncompromising dialog into equally unavoidable strips of graphic signs conveying a maximum of semantic and stylistic information. In this balancing act, the subtitler (consciously or not) utilizes certain techniques, but as is the case with any type of translation the goal of adequacy - and even less equivalence - is not always reached. (Gottlieb 1992: 166)

As it can be deduced, subtitling is a cross-medium activity (Bogucki 2004: 72) that renders spoken language in writing, with additional information visible on the screen. In this respect, it is considered to be a diagonal form of translation, one in which interlingual subtitles cross over from SL speech to TL script (Gottlieb 2004: 17). It is a form of overt translation (House 1997) as the subtitles are visible and are an inherent part of the subtitling activity (Munday 2008: 189). Taken from the position of text type, as the subtitles retain verbal elements of the ST, it can be considered "a written, additive, synchronous type pf translation of a fleeting polysemiotic text type" (Gottlieb 1997: 312).

As mentioned also in Gottlieb's definition, subtitles must follow certain technical, punctuational, and linguistic requirements. From a technical point of view, subtitles must appear in synchrony with the image and dialogue, and they must be displayed on the screen long enough for the viewers to be able to read them. Spatial and temporal limitations are imposed by the film medium. In this respect, subtitles are different from translations, and so subtitling is considered to be a kind of adaptation rather than translation. The technical limitations impose constraints on the end result. According to the generally accepted rule, there can be 32-41 characters per line and max. 2 lines per frame.

As the qualitative analysis of subtitles leads to a better understanding of the hows and whys of the subtitling process, in this paper we will concentrate on the linguistic (textual and translational) aspects of subtitles, i.e. on the verbal dimension of the text. From this point of view, certain guidelines have been settled (e.g. Díaz Cintas-Remael 2007: 147-183) according to which in subtitles the grammar and lexis tend to be simplified, while interactional features and intonation are maintained only to some extent. Not all features of speech are lost, but rendering all speech features would lead to long (and thus illegible) subtitles.

Besides, Chuchotage is a multilingual film, where the majority of the spoken text is in Hungarian, but, as the context of the film dialogue is the world of international interpreters, there are sequences in English and Italian as well. 
These languages add a "foreign touch" to the film, which might be in danger to be lost in the subtitles unless the viewer can rely on the soundtrack (Díaz CintasRemael 2007: 58).

Regarding the linguistic aspect of subtitles, researchers define subtitling as a form of rewriting which involves a great deal of text reduction due to the abovementioned technical constraints. Partial reduction means the condensation of the ST message, while total reduction involves deletions and omissions of some segments of the ST (Díaz Cintas-Remael 2007: 144-183). In deciding how much should be reduced or deleted, the principle of relevance should be applied (as argued in Gutt 1991). This means that a "balance between the effort required by the viewer to process an item and its relevance for the understanding of the film narrative" should be achieved, i.e. "achieving a maximum effect with a minimum effort" (Díaz Cintas-Remael 2007: 148). Naturally, when deciding what strategies to apply in the subtitling process, other aspects, such as genre, the target audience, the context, and the speed of delivery, should also be taken into account (Georgakopoulou 2003, qtd in Díaz Cintas-Remael 2007: 149). Consequently, the subtitles are aimed at producing a translation that is well tuned to the needs of the target audience (Díaz Cintas-Remael 2007: 149).

Based on his experience as a television subtitler, Gottlieb enlists ten strategies which are used by subtitlers. These are the following: 1) Expansion, 2) Paraphrase, 3) Transfer, 4) Imitation, 5) Transcription, 6) Dislocation, 7) Condensation, 8) Decimation, 9) Deletion, and 10) Resignation. The following table is taken from Gottlieb's categories of subtitling. This table consists of different types of subtitling strategies with the characteristics of each one as well as the media type they are specific to (Gottlieb 1992: 166):

Table 1. Gottlieb's typology of subtitling (1992) strategy, adapted by the author

\begin{tabular}{llc}
\hline $\begin{array}{c}\text { Types of } \\
\text { strategy }\end{array}$ & \multicolumn{1}{c}{ Character of translation } & $\begin{array}{c}\text { Media- } \\
\text { specific type }\end{array}$ \\
\hline 1) Extension & $\begin{array}{l}\text { Expanded expression, adequate rendering (e.g. culture- } \\
\text { specific references) }\end{array}$ & No \\
\hline 2) Paraphrase & $\begin{array}{l}\text { Altered expression, adequate content (non-visualized } \\
\text { language-specific phenomena) }\end{array}$ & No \\
\hline 3) Transfer & $\begin{array}{l}\text { Full expression, adequate rendering (“neutral” } \\
\text { discourse, slow tempo) }\end{array}$ & No \\
\hline 4) Imitation & $\begin{array}{l}\text { Identical expression, equivalent rendering (proper } \\
\text { nouns, international greetings, etc.) }\end{array}$ & Yes \\
\hline 5) Transcription & $\begin{array}{l}\text { Anomalous, non-standard expression, adequate } \\
\text { rendering (non-standard speech, intended speech } \\
\text { defects) }\end{array}$ & Yes \\
\hline 6) Dislocation & $\begin{array}{l}\text { Differing expression, adjusted content (musical or } \\
\text { visualized language-specific phenomena) }\end{array}$ \\
\hline
\end{tabular}




\begin{tabular}{llc}
\hline \multicolumn{1}{c}{$\begin{array}{c}\text { Types of } \\
\text { strategy }\end{array}$} & \multicolumn{1}{c}{ Character of translation } & $\begin{array}{c}\text { Media- } \\
\text { specific type }\end{array}$ \\
\hline 7) Condensation & $\begin{array}{l}\text { Condensed expression, concise rendering (normal, } \\
\text { mid-tempo speech with some redundancy) }\end{array}$ & Yes \\
\hline 8) Decimation & $\begin{array}{l}\text { Abridged expression, reduced content (fast speech of } \\
\text { some importance, i.e. low-redundancy speech) }\end{array}$ & Yes \\
\hline 9) Deletion & $\begin{array}{l}\text { Omitted expression, no verbal content (fast speech of } \\
\text { less importance, i.e. high-redundancy speech) }\end{array}$ & Yes \\
\hline \multirow{2}{*}{ 10) Resignation } & $\begin{array}{l}\text { Deviant, differing expression, distorted content } \\
\text { (incomprehensible or “untranslatable” speech such as } \\
\text { tricky idioms and culture-specific elements) }\end{array}$ & No \\
\hline
\end{tabular}

As it can be seen from the above table, strategies 1-7 are used in translation in general, and strategies 5-9 are more common in subtitling. Condensation (Strategy 7) is the prototypical strategy of subtitling as meaning and stylistic content are conveyed, but oral features are possibly lost. Semantic and stylistic content suffer the most in the case of decimation and deletion (strategies 8-9), where radical cuts are employed, but due to the presence of the audio and visual track the message is still delivered (Gottlieb 1992: 166-167).

Whenever there is a qualitative analysis of the way the ST is rendered in the TT, each verbal film segment must be analysed with respect to their semantic and stylistic value. In the following, relevant fragments of the script and the subtitles of the film Chuchotage will be compared and analysed, the selection of the examples being based on the specifics of the Hungarian language and culture.

\section{Methodology}

In most cases, it is the script of the film that forms the basis for the film dialogues and, consequently, for the subtitles. In our case, however, the script is not strictly followed by the actors. In one of the most important scenes, for instance, the actor was improvising, which made the audio version even more dynamic and realistic (see: interview fragment). ${ }^{2}$

In order to be able to compare the source text script and the subtitles of the short film Chuchotage, the following steps were followed: When the film was shortlisted for the Oscar Awards, it was made available online by its producers and was shared on several sites throughout the Hungarian media. So, in the first stage, the work was started by watching the Hungarian version of the film together with its English subtitles. In the second stage, the English subtitles were

2 http://www.miromagazine.com/film-tv/reviews-film-tv/chuchotage-review-a-mesmerisingmarriage-of-comedy-and-tragedy/?fbclid=IwAR2kXgbNscj_gaoUSHy0x59WZ2vQMCR lksUttRXq_zypY3TmqDvvh7XBeX0 
transcribed from the screen. Then the two Hungarian scripts of the movie were acquired by approaching the film director, Barnabás Tóth, who provided us with both the pre- and post-production scripts and some information regarding the subtitling process. ${ }^{3}$ Finally, a database was compiled, and both the source and target texts were placed in a chart for the sake of textual comparison.

\section{The story of little men in the shadows}

Being people "in the shadows", who are "only" mediators between languages and cultures, it is quite a rare occasion for translators or interpreters to become protagonists of a film. Suffice it to mention some feature film examples from recent years: The Interpreter ${ }^{4}$ (2005), The Translator ${ }^{5}$ (2015), Un Traductor ${ }^{6}$ (2018). Chuchotage is a film with a similar topic but this time in the form of a short, only 16-minute-long masterpiece.

According to its story, during a professional conference on the use of home appliances and their effect on environmental protection and climate change held in Prague, two simultaneous interpreters in the Hungarian booth are informed that only one person is listening to them. The two men try to detect the identity of the person among the listeners, and when this is revealed to them they compete with each other for the person's attention as in their belief the listener proves to be an attractive woman (hence the working title of the film: Flört (Flirt)). Ironically, the trick of the tale is revealed at the very end: the flirt is actually based on a misunderstanding, and the listener turns out to be a middle-aged man.

The film conveys a sweet and bitter central European image of the little man who - having spent all his life in an interpreting booth as a shadow character of conferences - yearns for the lost connection with the world beyond his booth. In this respect, it is a film about spaces in between, as one of its critics described it: "It is a film of translation and transcendence."

3 I am extremely grateful to Barnabás Tóth for providing me with the two scripts of the film. The subtitles were created by Ágnes Székely, in the case of puns and wordplay helped by the director, Barnabás Tóth himself, and his brother (personal communication).

https://www.imdb.com/title/tt0373926/

https://www.youtube.com/watch?v=PA8HTX6CXBs

https://www.imdb.com/title/tt4488744/

http://www.miromagazine.com/film-tv/reviews-film-tv/chuchotage-review-a-mesmerisingmarriage-of-comedy-and-tragedy/?fbclid=IwAR2kXgbNscj_gaoUSHy0x59WZ2vQMCRlks UttRXq_zypY3TmqDvvh7XBeX0 


\section{The subtitling of Chuchotage - Spaces in between}

In this part of the paper, the spaces in between the source text (the sound track) and its subtitles will be examined with respect to Gottlieb's typology of subtitling strategies. Firstly, forms of address as well as formal and informal (slang) expressions will be studied as they appear in the two interpreters' dialogues and their English subtitles. Secondly, the culture-specific elements of the source culture as well as the way they are rendered in the subtitles will be analysed. Last but not least, the wordplay and humorous remarks will be discussed as phrases which occasionally prove to be untranslatable items.

\subsection{Rendering forms of address, formal and informal expressions}

In the film, the two Hungarian interpreters are called András (Andrew) and Pál (Paul), but they address each other as "Andriskám" and "Palikám" (Andrew/Paul + diminutive + first-person possessive pronoun "my"), suggesting the speaker's scornful and educating attitude towards his addressee.

In the English subtitles, however, the two names appear either as the regular Hungarian first name (András $=$ Andrew) or replaced by a more impersonal, general form of address: my friend. The kindness and banter meant by the use of the Hungarian forms of address are lost in the English variants, and so this friendly relationship shared by the two is not verbally signalled. However, we believe that this loss is compensated visually by the characters' facial expressions and gestures.

Table 2. Examples - Part I.

\begin{tabular}{llll}
\hline & HU script & EN subtitles & Back translation \\
\hline 1. & $\begin{array}{l}\text { P: Andriskám, lehet } \\
\text { egy olyat kérni, hogy } \\
\text { legközelebb reggelizz a } \\
\text { szállodában? }\end{array}$ & $\begin{array}{l}\text { P: András, can I ask you } \\
\text { to have breakfast at the } \\
\text { hotel next time? }\end{array}$ & $\begin{array}{l}\text { Andrew + diminutive + } \\
\text { pers. poss., is it possible } \\
\text { to ask that you have your } \\
\text { breakfast in the hotel next } \\
\text { time? }\end{array}$ \\
\hline $\begin{array}{lll}\text { A: Ezt majd te csinálod, } \\
\text { Palikám. }\end{array}$ & $\begin{array}{l}\text { A: That's going to be your } \\
\text { bit, my friend. }\end{array}$ & $\begin{array}{l}\text { A: Then you will do this, } \\
\text { Paul + diminutive }+1^{\text {st }}- \\
\text { pers. poss. }\end{array}$ \\
\hline
\end{tabular}

A similar Hungarian endearing form of address is magácska (you - sg. fml. dimin.), which is a personal pronoun in the process of becoming outdated and mostly used by men to kindly address young girls. It is a diminutive form of the formal honorific maga (you - sg. fml.). Today, it already has an ambiguous, slightly erotic taste. In examples 3-5 below, this form of address is used in this connotation when András addresses the Woman, flirting with her more and more aggressively. 
Table 3. Examples - Part II.

\begin{tabular}{|c|c|c|c|}
\hline & HU script & EN subtitles & Back translation \\
\hline 3. & $\begin{array}{l}\text { András: Magácska ott } \\
\text { a hátsó sorban viszont } \\
\text { szerintem abszolút A } \\
\text { kategóriás. }\end{array}$ & $\begin{array}{l}\text { You dear, in the back row } \\
\text { however could definitely } \\
\text { be labelled as A. }\end{array}$ & $\begin{array}{l}\text { You (sg. fml. dimin.) there } \\
\text { in the back row, however, I } \\
\text { think you are absolutely A } \\
\text { category. }\end{array}$ \\
\hline 4. & $\begin{array}{l}\text { András: Ilyen magácska is, } \\
\text { ebben nem nyitok vitát. }\end{array}$ & $\begin{array}{l}\text { Just like you, no use } \\
\text { arguing about that. }\end{array}$ & $\begin{array}{l}\text { You (sg. fml. dimin.) are } \\
\text { also like this, I do not } \\
\text { open a discussion about } \\
\text { that. }\end{array}$ \\
\hline 5. & $\begin{array}{l}\text { András: (...) az } \\
\text { állampolgárok, mint } \\
\text { magácska és én, } \\
\text { gyakorlatilag leadhatják a } \\
\text { régi eszközöket. }\end{array}$ & $\begin{array}{l}\text { Where citizens like you } \\
\text { and me can take our old, } \\
\text { unused sexual tools. }\end{array}$ & $\begin{array}{l}\text { (...) the citizens, like you } \\
\text { (sg. fml. dimin.) and me, } \\
\text { can practically hand down } \\
\text { the old tools. }\end{array}$ \\
\hline
\end{tabular}

However, as it can be seen from the English context, the rendering of this pronoun appears only once in the form of you dear, whereas in the other cases it remains the simple personal pronoun you. It is true that the honorific forms of address existing in Hungarian (ön, maga) cannot be translated literally, wherefore compensating strategies are required in the translation to render the respect shown by the addresser towards the addressee.

Pál, on the other hand, keeps addressing the Woman as maga, showing genuine respect towards her all through his self-confession in the culminating monologue of the film. Similar to András's dialogues, this is rendered by "you" in the English subtitles; so, the foreign viewer does not notice any textual difference in the two men's totally different attitude towards the woman. However, we believe, this contrast is again compensated by the two characters' different facial expressions, body movement, and gestures. Moreover, the different attitude is also highlighted by the way Pál tries to compete for her by mentioning the difficulties of his profession (SZAKMA! 'PROFESSION!' - he writes a note to his colleague in capital letters suggesting that the woman's attention should be drawn by doing their best as interpreters), while András tries to conquer her by courting her, referring to her physical qualities. 
Table 4. Examples - Part III.

\begin{tabular}{|c|c|c|c|}
\hline & HU script & EN subtitles & Back translation \\
\hline 6. & $\begin{array}{l}\text { Pál: Szigorú szabályok } \\
\text { közt élek. Soha semmi } \\
\text { nem zökkenthet ki. De } \\
\text { aztán jön maga. }\end{array}$ & $\begin{array}{l}\text { I live by strict rules, } \\
\text { nothing ever puts me off. } \\
\text { Except you. }\end{array}$ & $\begin{array}{l}\text { I live among strict rules. } \\
\text { Nothing ever can put me } \\
\text { off. But then you (sg. fml.) } \\
\text { appear. }\end{array}$ \\
\hline 7. & $\begin{array}{l}\text { Pál: Látom, hogy itt van } \\
\text { maga körül } 70 \text { ember és } \\
\text { senki nem hallja, amit } \\
\text { mondok, csak maga. }\end{array}$ & $\begin{array}{l}\text { There are } 70 \text { people in } \\
\text { that room, but you are the } \\
\text { only one hearing me. }\end{array}$ & $\begin{array}{l}\text { I can see that there are } \\
70 \text { people around you } \\
\text { (sg. fml.), and nobody } \\
\text { can hear what I'm saying } \\
\text { except you (sg. fml.). }\end{array}$ \\
\hline 8. & $\begin{array}{l}\text { Pál: Maga miatt kilépek } \\
\text { az árnyékból a fényre, } \\
\text { maga elé. Ön nem tud } \\
\text { angolul, de majd leszek } \\
\text { az ön tolmácsa. Eljövök } \\
\text { mindenhova, maga } \\
\text { mögé ülök, és sustorgok } \\
\text { a fülébe. Megmutatom } \\
\text { magának, mi az a } \\
\text { susotázs. }\end{array}$ & $\begin{array}{l}\text { For you I would step out } \\
\text { of the shadows into the } \\
\text { light. You don't speak } \\
\text { English, but I will be your } \\
\text { interpreter. I'll follow } \\
\text { you everywhere, sitting } \\
\text { behind you. Whispering } \\
\text { into your ear. Showing } \\
\text { you what chuchotage is. }\end{array}$ & $\begin{array}{l}\text { Because of you (sg. fml.) } \\
\text { I step out of the shadow } \\
\text { into the light in front } \\
\text { of you. You can't speak } \\
\text { English, but then I will } \\
\text { be your interpreter. I will } \\
\text { come everywhere, will be } \\
\text { sitting behind you, and } \\
\text { will be whispering into } \\
\text { your ear. I will show you } \\
\text { what chuchotage is. }\end{array}$ \\
\hline
\end{tabular}

In Example (8) the honorific pronoun ön also appears twice, as the official formal expression for second person address, but this is similarly rendered in the English subtitles by you, wherefore again the foreign-language viewer does not notice any difference in the degree of formality in the verbal behaviour of the two interpreters when addressing the Woman. We believe that Paul's very respectful confession compensates for this loss.

\subsection{Rendition of informal language and slang}

Rendering informal expressions can also cause slight hesitations for the subtitler. Due to the informal situation in which the plot of the film takes place, the script of Chuchotage also contains several informal words, phrases, and slang expressions that had to be translated into/adapted to English. In the first place, there are international words that have been taken over from English into Hungarian, and therefore their rendition probably did not pose a problem (e.g. forms of greeting such as "hello", which was not even subtitled as the viewer can hear it directly and will surely understand). Similar examples can be seen below: 
Table 5. Examples - Part IV.

\begin{tabular}{|c|c|c|c|}
\hline & HU script & EN subtitles & Back translation \\
\hline 9. & $\begin{array}{l}\text { Muszáj volt } \\
\text { shoppingolnom reggel. Az } \\
\text { asszony valami speckó } \\
\text { sajtokat rendelt, ami ugye } \\
\text { nincs a repülő́téren. }\end{array}$ & $\begin{array}{l}\text { I had to go shopping. } \\
\text { My wife asked for some } \\
\text { special cheese. }\end{array}$ & $\begin{array}{l}\text { I had to go shopping in } \\
\text { the morning. The woman } \\
\text { (= my wife) ordered some } \\
\text { special kinds of cheese, } \\
\text { which, as you know, } \\
\text { cannot be found at the } \\
\text { airport. }\end{array}$ \\
\hline 10. & $\begin{array}{l}\text { A múltkor egy barokk } \\
\text { konferenciát csináltam, } \\
\text { ahol a nő mellettem } \\
\text { melegítette az instant } \\
\text { leves port, miközben én } \\
\text { tolmácsoltam. }\end{array}$ & $\begin{array}{l}\text { I did a conference on } \\
\text { Baroque with a woman } \\
\text { who boiled instant soup } \\
\text { next to me while I was } \\
\text { interpreting. }\end{array}$ & $\begin{array}{l}\text { The other day, I did a } \\
\text { conference on Baroque, } \\
\text { where the woman next } \\
\text { to me was heating the } \\
\text { instant soup powder, } \\
\text { while I was interpreting. }\end{array}$ \\
\hline 11. & Valami nagy fejes lehet. & It must be some bigwig. & $\begin{array}{l}\text { It must be some kind of } \\
\text { big boss. }\end{array}$ \\
\hline 12. & $\begin{array}{l}\text { Biztos valami vén komcsit } \\
\text { küldtek. }\end{array}$ & $\begin{array}{l}\text { Must be some old } \\
\text { commie, they sent. }\end{array}$ & $\begin{array}{l}\text { Surely they sent some old } \\
\text { communist (dimin.). }\end{array}$ \\
\hline
\end{tabular}

The last two examples (11-12) show two different types of common slang phrases, typical idiomatic expressions which have been rendered in the English subtitles by employing similar idiomatic phrases. The Hungarian "fejes" is frequently used in pejorative contexts, meaning "an important, influential person" (Kövecses 2002: 94). The English slang term "bigwig" does not have this pejorative connotation here as it means "a powerful, important person, often a politician or bureaucrat", ${ }^{8}$ but the core meaning and the register as well as the length of the word are the same. Similarly, the Hungarian slangy idiomatic expression vén komcsi 'old communist' has an ironic reference, which has been rendered as "old commie", having a negative, derogatory connotation, meaning "communist, today used to refer to Slavic people or those of Russian or Eastern European descent". ${ }^{9}$ The subtitler's choice is proper as the context of the dialogue is conference interpretation in Prague, where (ironically) the delegate of a reputable old Hungarian refrigerator factory can only be somebody who remained there as a relic of communist times and who needs interpretation as a non-English speaker.

Obviously, informal language also appears in the English subtitles in the form of phrasal verbs (Jaj, úgy unom ezeket a szar kajákat. 'I'm so fed up with this shitty food.') or taboo words (Nem kell beszarni. 'Don't shit yourself.') In the choice of the latter, the subtitler is brave enough not to avoid them but remains within the limits of decency.

8 https://greensdictofslang.com/entry/ydabz3y

9 https://www.urbandictionary.com/define.php?term=Commie 


\subsection{The Eastern European touch: Culture-specific elements}

As a Hungarian film showing a conference in Prague on environmental issues, the soundtrack (script) contains geographical names (Jászberény, Prague, Czech Republic), brand names (LEHEL), and names of institutions (MÉH) related to Hungary. These are transferred to the subtitles without change or by employing the English spelling of the particular geographic location. The name of the company (MÉH - Melléktermék- és Hulladékhasznosító Vállalat 'Residual By-Product and Waste Recycling Company') was completely deleted due to technical constraints and because the wordplay inherent in the name (to be discussed below) could not be rendered in Hungarian.

Naturally, these culture-specific items do not have the same connotation for a foreign language viewer as for a Hungarian one, but the context helps in correctly identifying the right message.

Table 6. Examples - Part V.

\begin{tabular}{|c|c|c|c|}
\hline & HU script & EN subtitles & Back translation \\
\hline 13. & $\begin{array}{l}\text { A: Gyártunk mi egyáltalán } \\
\text { hútőszekrényt? } \\
\text { P: Hogyne. LEHEL gyár } \\
\text { van Jászberényben. } \\
\text { A: Leheeeel! } \\
\text { Gyerekkoromban } \\
\text { hallottam utoljára ezt a } \\
\text { márkanevet. S a Lehelnél } \\
\text { nem tudnak angolul? }\end{array}$ & $\begin{array}{l}\text { A: Do we even produce } \\
\text { fridges? } \\
\text { P: Of course we do. } \\
\text { There is this factory in } \\
\text { Jászberény, called LEHEL. } \\
\text { A: Lehel! Last time I heard } \\
\text { this name I was a child. } \\
\text { And they don’t speak } \\
\text { English at Lehel? }\end{array}$ & $\begin{array}{l}\text { A: Do we even produce } \\
\text { fridges? } \\
\text { P: Of course. There is a } \\
\text { LEHEL ( = exhale) factory } \\
\text { in Jászberény. } \\
\text { A: Lehel! I last heard } \\
\text { this brand name in my } \\
\text { childhood. And they can't } \\
\text { speak English at Lehel? }\end{array}$ \\
\hline 14. & $\begin{array}{l}\text { gyújtőpontokat kellett } \\
\text { felállítani, lásd korábban } \\
\text { a MÉH, ugye nem az } \\
\text { állat... }\end{array}$ & $\begin{array}{l}\text { Municipalities need to set } \\
\text { up collection points. }\end{array}$ & $\begin{array}{l}\text { collection points had to } \\
\text { be set up, see previously } \\
\text { MÉH (= bee/womb), you } \\
\text { see, not the animal... }\end{array}$ \\
\hline 15. & $\begin{array}{l}\text { Mér’ nem tudnak egy jó } \\
\text { kis juhtúrós sztrapacskát } \\
\text { kirakni? Elvégre } \\
\text { Csehországban vagyunk, } \\
\text { nem? }\end{array}$ & $\begin{array}{l}\text { Why can't they serve } \\
\text { a good halushky for a } \\
\text { change? We are in the } \\
\text { Czech Republic after all. }\end{array}$ & $\begin{array}{l}\text { Why can't they put out } \\
\text { some good strapachka } \\
\text { 'dumplings' with sheep } \\
\text { cheese? After all, we are } \\
\text { in Czechia, aren't we? }\end{array}$ \\
\hline 16. & $\begin{array}{l}\text { Megehetted volna } \\
\text { valamelyik szünetben is } \\
\text { azt a lazacos szendvicset } \\
\text { vagy lophattál volna egy } \\
\text { makaront inkább. }\end{array}$ & $\begin{array}{l}\text { You could have eaten the } \\
\text { salmon sandwich in one } \\
\text { of the breaks. Or could } \\
\text { have simply taken a } \\
\text { macaroon. }\end{array}$ & $\begin{array}{l}\text { You could have eaten } \\
\text { that salmon sandwich in } \\
\text { one of the breaks, or you } \\
\text { could have rather stolen a } \\
\text { macaron. }\end{array}$ \\
\hline
\end{tabular}

The names of food items (sztrapacska-halushky, makaron-macaroon) are dislocated in the subtitles, the terms being adapted for an international audience. The Hungarian sztrapacska is a traditional variety of thick, soft noodles or 
dumplings, cooked in Central and Eastern European, mainly Slovak and Czech cuisines, which contains grated raw potatoes (the meaning of the word strapatý is 'rattled', 'unkempt') and is usually served with sour cabbage and meat. In Hungary, it is frequently mistaken for bryndzové halusky, which is served with sheep's cheese and bacon. It is in this sense that it is used in the script as well. Halušky can refer to the dumplings themselves or to the complete dish - this latter reference is used in the subtitles. Regarding the transfer of the Hungarian makaron, we find a misspelling in the subtitles as there is a difference between French macarons (spelt with one 'o') and coconut macaroons (spelt with double 'o'), which translates into Hungarian as "mandulás csók” (lit. 'a kiss with almonds'). ${ }^{10}$

As it can be seen in Example (16), there is a further hint at the Eastern European attributes of these characters as it appears in their verbal and non-verbal behaviour. The Hungarian soundtrack tells us about Pál's advice to András, suggesting that he should have stolen a macaroon. However, the subtitler generalizes the verb "steal" to its hypernym (taken). In another scene, before starting their work as interpreters, the technician asks them what language they interpret into; Pál has an apologetic expression on his face and tone of voice when he utters the word "Hungarian" as if he meant "Sorry, it’s only Hungarian, small language, insignificant nation."

\subsection{Rendering humour and wordplay}

Last but not least, the humour, especially the verbal humour of the film, is what makes it special and challenging for the subtitler. The two interpreters make a deal: "The one who makes her laugh can have her!" In order to make her smile, András starts telling erotic ambiguities into the woman's headphones. While interpreting the conference speaker's words into Hungarian, knowing (actually believing) that it is only the woman who hears him, he uses words, phrases that lead to double meaning (see examples 17-23).

Table 7. Examples - Part VI.

\begin{tabular}{|c|c|c|c|}
\hline & HU script & EN subtitles & Back translation \\
\hline 17. & $\begin{array}{l}\text { Azonban akkoriban még } \\
\text { csak a C kategóriát érték } \\
\text { el a legjobb termékek. } \\
\text { Magácska ott a hátsó } \\
\text { sorban viszont szerintem } \\
\text { abszolút A kategóriás. } \\
\text { Azok a termékek } \\
\text { szépültek, kerekedtek, } \\
\text { domborult... }\end{array}$ & $\begin{array}{l}\text { When the first label was } \\
\text { introduced, the best } \\
\text { products were labelled } \\
\text { as C. You dear, in the } \\
\text { back row however could } \\
\text { definitely be labelled as A. } \\
\text { Products have improved, } \\
\text { got a fancier look, } \\
\text { smoother touch, rounder } \\
\text { curves... }\end{array}$ & $\begin{array}{l}\text { However, back then the } \\
\text { best products reached only } \\
\text { category C. You (sg. fml. } \\
\text { dimin.) there in the back } \\
\text { row, however, I think you } \\
\text { are absolutely A category. } \\
\text { Those products have } \\
\text { become nicer, rounder, } \\
\text { curvier... }\end{array}$ \\
\hline
\end{tabular}

10 https://www.thespruceeats.com/difference-between-macarons-and-macaroons-435337 


\begin{tabular}{|c|c|c|c|}
\hline & HU script & EN subtitles & Back translation \\
\hline 18. & $\begin{array}{l}\text { Javítok: maga egyenesen } \\
\text { A+-os, még így félprofilból } \\
\text { is. }\end{array}$ & $\begin{array}{l}\text { Update: you are an } \mathrm{A}+ \\
\text { even from this angle. }\end{array}$ & $\begin{array}{l}\text { I correct myself: you are } \\
\text { directly an A+, even like } \\
\text { this, from semi-profile. }\end{array}$ \\
\hline 19. & $\begin{array}{l}\text { Én megfelelően kezelném } \\
\text { magát... }\end{array}$ & $\begin{array}{l}\text { We could do something } \\
\text { more effective together. }\end{array}$ & $\begin{array}{l}\text { I could treat you in a } \\
\text { proper way... }\end{array}$ \\
\hline 20. & $\begin{array}{l}\text {..ugyanis az Európai Unió } \\
\text { jogszabálya különböző } \\
\text { kívánalmakat... igen, } \\
\text { kívánom, kívánom... }\end{array}$ & $\begin{array}{l}\text {...material recovery has } \\
\text { been further promoted by } \\
\text { legal needs introduced by } \\
\text { EU waste legislation. Yes- } \\
\text { yes needs, I need you! }\end{array}$ & $\begin{array}{l}\text {...namely the legislation } \\
\text { of the European Union ... } \\
\text { different needs ... yes, I } \\
\text { need you, I need you... }\end{array}$ \\
\hline 21. & $\begin{array}{l}\text { Az önkormányzatoknak } \\
\text { mindenképpen } \\
\text { gyújtőpontokat kellett } \\
\text { felállítani, lásd korábban } \\
\text { a MÉH, ugye nem az állat, } \\
\text { hanem az állampolgárok, } \\
\text { mint magácska és én, } \\
\text { gyakorlatilag leadhatják a } \\
\text { régi eszközöket. }\end{array}$ & $\begin{array}{l}\text { Municipalities need to } \\
\text { set up collection points. } \\
\text { Where citizens like you } \\
\text { and me can take our old, } \\
\text { unused sexual tools. }\end{array}$ & $\begin{array}{l}\text { The self-governments had } \\
\text { to set up collection points } \\
\text { at any rate, see previously } \\
\text { MÉH (= bee), you see, } \\
\text { not the animal, but the } \\
\text { citizens, like you and me, } \\
\text { can practically hand in the } \\
\text { old tools. }\end{array}$ \\
\hline 22. & $\begin{array}{l}\text { Házastársi, akarom } \\
\text { mondani, háztartási } \\
\text { hulladék különválasztása } \\
\text { fa, múanyag, papír, } \\
\text { mézeskalácsszív... }\end{array}$ & $\begin{array}{l}\text { The separation of pubic } \\
\ldots \text { uhm, public waste } \\
\text { into wood, plastic, paper, } \\
\text { mistletoe... }\end{array}$ & $\begin{array}{l}\text { Separation of spouse, I } \\
\text { mean, household waste } \\
\text { into wood, plastic, paper, } \\
\text { gingerbread heart... }\end{array}$ \\
\hline 23. & $\begin{array}{l}\text { Öntől eláll a lélegzetem. } \\
\text { Vagy mondjam úgy, hogy } \\
\text { „bennrekedt a LEHEL- } \\
\text { letem”? }\end{array}$ & $\begin{array}{l}\text { I'm totally escaping all } \\
\text { control here with you. You } \\
\text { took my bras away. }\end{array}$ & $\begin{array}{l}\text { You take my breath away. } \\
\text { Or should I say "my breath } \\
\text { gets stuck in"? }{ }^{11}\end{array}$ \\
\hline
\end{tabular}

The latter examples (21-23) deserve more attention for the analyst as they are based on word play. The name of the recycling company, MÉH (see above) is homonymous with two other nouns in Hungarian: the bee (an insect), which is also mentioned by the speaker, while the other homonym is the noun designating the woman's womb, which, in this context, acquires erotic, sexual connotation. As this triple homonymy could not be rendered word by word in the English subtitles, the translator followed the strategy of compensation: the erotic ambiguity was moved to another section of the sentence, referring to home appliance waste (unused sexual tools).

11 On this occasion, I would like to thank Szilárd Szentgyörgyi for providing another excellent solution for this pun: "You give me a chill. Or should I say, you take my frigid-aire?" In this case, the first part of the translation contains the phrase "give me the chills", where chill means "a moment of intense excitement, a sudden, passing sensation of excitement", while the Hungarian brand name Lehel is adapted and transformed into the American brand name Frigidaire, similarly a prestigious home appliance company in the US. Additional information is that, ironically, both the Hungarian and the American company have become subsidiaries of the Swedish Electrolux. 
The following example (22) begins with an apparently false start - the speaker uses two very similarly sounding words: házastársi 'marital' / 'conjugal' háztartási 'domestic'. This is very ingeniously rendered in the English subtitles as pubic vs public. The ambiguity mentioned above is maintained here. The list of domestic waste contains "wood, plastic, paper" but the noun gingerbread heart is also enlisted, as a Hungarian folk symbol of love. Obviously, if rendered word by word, this noun would not have had the same effect for an English-speaking viewer; therefore, it had to be replaced by another noun, possibly beginning with a similar consonant, $m$, and having the same connotation. The result was again a very creative solution: mistletoe, which is similarly a symbol of love in the Anglo-Saxon culture.

Finally, the Hungarian pun bennrekedt a LEHEL-letem in Example (23) is based on the similarity of the brand name LEHEL and its homonymous verb lehel 'breathe'. In this case, the translator offers the solution "You took my bras away". The verbal joke was solved as the subtitler concentrated on the acoustic similarity between the nouns breath and bras, thus trying to compensate for the Hungarian play on words.

\section{Conclusions}

In this paper, we have compared the Hungarian script and the English subtitles of the short film Chuchotage, analysing those linguistic aspects of the two texts that may have proved to be challenging for the subtitler due to the Hungarian "specialities": forms of address, informal language forms, culture-specific elements, and humour. As the analysis of the above examples readily reveals, the English subtitles come as a very good completion of the visual appeal of the film. The comic and dramatic, the sweet and bitter aspects of the movie are similarly rendered in the English subtitles, which, we believe, hence considerably added to the excellent reception of the film at international festivals.

The translator/subtitler operates in a hybrid, intermediary space, a space inbetween cultures and languages. This transgression of borders could be followed in the analysis of the English subtitles. Pál, the conference interpreter in Chuchotage, similarly crosses the borders of his own self and his own professional role as an interpreter by confessing his feelings to the Woman and by stepping out of the shade into the light, into visibility. Unfortunately, typical of an Eastern European character, he is disappointed. Hopefully, the viewers of this Hungarian film will be devoid of this feeling, also thanks to the English subtitles. 


\section{Acknowledgements}

I would like to thank my two anonymous reviewers for their corrections, recommendations, and kind remarks.

\section{References}

Bassnett, Susan. 2007. Culture and translation. In: Kuhiwczak, Piotr-Karin Littau (eds), A companion to translation studies. Clevedon: Multilingual Matters. 13-23.

Bogucki, Lukasz. 2004. The constraint of relevance in subtitling. The Journal of Specialized Translation 1: 71-88.

Díaz Cintas, Jorge. 2012. Subtitling. Theory, practice, and research. In: Millán, Carmen-Francesca Bartrina (eds), The Routledge handbook of translation studies. London-New York: Routledge. 273-287.

Díaz Cintas, Jorge-Aline Remael. 2007. Audiovisual translation. Subtitling. Manchester: St. Jerome Publishing.

Eco, Umberto. 2008. Experiences in translation. Toronto: Toronto University Press.

Gambier, Yves. 2018. Translation studies, audiovisual translation and reception. In: Di Giovanni, Elena-Yves Gambier (eds), Reception studies and audiovisual translation. Amsterdam/Philadelphia: John Benjamins. 43-66.

Gottlieb, Henrik. 1992. Subtitling: A new university discipline. In: Dollerup, Cay-Anne Loddegaard (eds), Teaching translation and interpreting: Training, talent and experience. Amsterdam/Philadelphia: John Benjamins. 161-170.

1997. Quality revisited: The rendering of English idioms in Danish television subtitles vs printed translations. In: Trosborg, Anna (ed.), Text typology and translation. Amsterdam and Philadelphia: John Benjamins. 309-338.

2004. Texts, translation and subtitling - In Theory, and in Denmark. Screen Translation 57: 1-40.

Gutt, Ernst-August. 1991. Translation and relevance: Cognition and context. Oxford: Blackwell.

House, Juliane. 1997. Translation quality assessment. A model revisited. Tübingen: Günter Narr.

2015. Translation quality assessment. Past and present. London-New York: Routledge.

Munday, Jeremy. 2008. Introducing translation studies. Theories and applications. London-New York: Routledge.

Shuttleworth, Mark-Moira Cowie. 1997. Dictionary of translation studies. Manchester: St. Jerome Publishing. 
Szarkowska, Agnieszka. 2005. The power of film translation. Translation Journal 9(2). http://translationjournal.net/journal/32film.htm.

\section{Dictionaries}

Green's Dictionary of slang. https://greensdictofslang.com

Kövecses, Zoltán. 2002. Magyar szlengszótár [Hungarian dictionary of slang]. Budapest: Akadémiai Kiadó. 